\title{
Pengaruh kopi Aceh ulee kareng terhadap kekerasan basis gigitiruan resin akrilik Effect of ulee kareng Aceh coffee the hardness of acrylic resin denture base
}

\author{
${ }^{1}$ Rini Defika Putri, ${ }^{2}$ Viona Diansari, ${ }^{3}$ Iin Sundari \\ ${ }^{1}$ Mahasiswa Tahapan Profesi \\ ${ }^{2}$ Program Studi Kedokteran Gigi \\ Fakultas Kedokteran Universitas Syiah Kuala \\ Darussalam - Banda Aceh, Indonesia
}

\begin{abstract}
The hardness of denture base is influenced with the habit of most commonly consumed. Ulee Kareng Aceh coffee was atype of robusta coffee which is acidic. The purpose of this study was to determine the change of surface hardness of acrylic denture base after being immersed in ulee kareng coffee for 3 days. Twelve specimens $(5 \mathrm{~mm}$ diameter and $2 \mathrm{~mm}$ thickness) were randomly distributed in two groups: control (immersion in distilled water) and experimental (immersion in Ulee Kareng Aceh coffee). Hardness was measured before and after immersion using Knoop Microhardness tester (Shimadzu). Data were statistically analyzed by Mann Whitney and Wilcoxon test ( $\alpha=$ 0.05). The results of the study showed a significant difference between the groups $P<0.05$. The surface hardness of acrylic denture base decreased after immersion for both group $P<0.05$.
\end{abstract}

Key words: acrylic resins, Ulee Kareng Aceh coffee, hardness

\begin{abstract}
ABSTRAK
Kekerasan basis gigitiruan dapat dipengaruhi oleh makanan dan minuman yang sering dikonsumsi pasien. Kopi Aceh Ulee Kareng merupakan kopi robusta yang bersifat asam. Tujuan dari penelitian ini adalah untuk mengetahui perubahan kekerasan basis gigitiruan resin akrilik setelah direndam dalam kopi Aceh Ulee Kareng selama 3 hari. Penelitian ini menggunakan 12 spesimen resin akrilik (diameter $5 \mathrm{~mm}$ dan tebal $2 \mathrm{~mm}$ ) yang dibagi ke dalam 2 kelompok perendaman, yaitu kelompok kontrol (akuades) dan kelompok perlakuan (kopi Aceh Ulee Kareng). Pengujian kekerasan dilakukan sebelum dan sesudah perendaman dengan menggunakan alat Knoop Microhardness Tester (Shimadzu). Analisis data menggunakan Mann Whitney menunjukkan ada perbedaan nilai kekerasan yang signifikan $(\mathrm{P}<0,05)$ antara kelompok kontrol dengan kelompok perlakuan. Dari uji Wilcoxon diperoleh penurunan nilai kekerasan yang signifikan pada kedua kelompok.
\end{abstract}

Kata kunci: basis gigitiruan resin akrilik, kopi Aceh Ulee Kareng, kekerasan Knoop

Korespondensi: Rini Defika Putri, Program Studi Kedokteran Gigi, Fakultas Kedokteran Universitas Syiah Kuala. Darussalam, Banda Aceh, Indonesia. Telp. (0651) 7411794.E-mail: defika_putri@yahoo.com.

\section{PENDAHULUAN}

Bahan dasar basis gigitiruan yang paling sering digunakan dalam bidang kedokteran gigi adalah polimetil metakrilat atau sering disebut resin akrilik jenis heat cured. Bahan tersebut mempunyai banyak keuntungan seperti mudah didapat, teknik aplikasi yang relatif sederhana, hasil estetik yang memuaskan dan sudah sangat dikenal. ${ }^{1,2}$ Resin akrilik, selain memiliki sifat yang menguntungkan, juga mempunyai kekurangan, seperti menyerap bahan cair, baik air maupun bahan kimia dan sisa makanan. Penyerapan bahan minuman yang mengandung asam akan bereaksi secara kimia dengan resin akrilik dan menetap di dalam pori-pori resin akrilik. ${ }^{3-5}$ Menurut penelitian Craig dan Payton resin akrilik dapat dipengaruhi oleh asam asetat, yaitu dengan konsentrasi yang semakin meningkat atau $\mathrm{pH}$ yang tinggi akan melemahkan ikatan polimer resin akrilik. Hal ini didukung oleh penelitian Hayashi et al, bahwa salah satu akibat dari kebiasaan mengkonsumsi minuman yang mengandung asam akan menimbulkan kerusakan pada gigitiruan resin akrilik. $^{4}$

Kopi merupakan salah satu minuman yang mengandung beberapa zat kimia yang biasa dikelompokkan menjadi asam dan menjadi karakter dari beberapa jenis kopi Robusta. ${ }^{6}$ Hasil penelitian menunjukkan kopi yang telah dilarutkan dalam air masih menyisakan kandungan asam, yaitu asam klorogenat dan trigonelin yang semula $7,60 \%$ dan $1,70 \%$ menjadi $0,80 \%$ dan $0,29 \%$. $^{7}$ Pada pengujian $\mathrm{pH}$ ditemukan bahwa kopi memiliki $\mathrm{pH}$ 3,0 dan sifat asam kopi dapat menyebabkan erosi pada lapisan permukaan resin akrilik yang telah dipoles sehingga meningkatkan terbentuknya stain. ${ }^{8}$ Kopi juga memiliki banyak gugus fenol dalam molekulnya. ${ }^{9-11}$ Menurut penelitian Shen, disinfektan yang mengandung fenolic buffer dapat menyebabkan pitting dan 
pelunakan pada permukaan resin akrilik heatcured setelah 2 hari perendaman. Kemudian menurut Othmer, fenol, cresol dan asam format dapat melarutkan polimer pada suhu kamar. ${ }^{12}$

Tradisi minum kopi telah dikenal masyarakat pada berbagai negara. Khususnya di Aceh, konsumsi kopi oleh masyarakat yang menjadikan kedai kopi sebagai tempat tongkrongan dan hiburan utama sangat tinggi. Mulai dari pagi, siang, sore hingga malam hari tiap orang dapat menghabiskan 3-4 cangkir kopi dalam sehari. ${ }^{13}$ Diantara sekian banyak peminum kopi di Aceh tentu banyak pula yang memakai gigitiruan dari bahan resin akrilik. Menurut Philips, resin akrilik mempunyai sifat porus dan mudah menyerap cairan. ${ }^{3}$ Sehingga diduga dapat terjadi penyerapan kopi ke dalam resin akrilik pada pengkonsumsi kopi Ulee Kareng, kemudian dengan adanya kandungan polifenol dan asam yang terkandung dalam kopi tersebut maka kemungkinan kopi Ulee Kareng yang terserap ke dalam resin akrilik akan mempengaruhi kekerasannya. ${ }^{8-10}$ Oleh karena itu dilakukan penelitian untuk mengetahui penurunan nilai kekerasan resin akrilik setelah perendaman dalam minuman kopi Ulee Kareng selama 3 hari (diasumsikan selama 6 bulan pemakaian).

Pada artikel ini dipaparkan hasil penelitian mengenai perendaman specimen resin akrilik dalam kopi Aceh Ulee Kareng akan menurunkan kekerasan basis gigitiruan resin akrilik.

\section{BAHAN DAN METODE}

Penelitian eksperimental laboratoris ini menggunakan 12 spesimen lempeng resin akrilik jenis heat cured merek QC 20 (diameter $5 \mathrm{~mm}$ dan tebal $2 \mathrm{~mm}$ ), dengan kriteria permukaan spesimen halus dan rata, tidak berbintil, tidak porus, dan tidak ada perubahan bentuk. Sampel dibagi menjadi 2 kelompok; kelompok I (kelompok kontrol), plat akrilik direndam dalam akuades selama 3 hari, dan kelompok II (kelompok perlakuan), plat akrilik direndam dalam larutan kopi Ulee Kareng selama 3 hari. Lamanya resin akrilik yang direndam dalam minuman kopi Ulee Kareng selama 3 hari diasumsikan dengan pemakaian resin akrilik sebagai basis gigitiruan selama 6 bulan, dengan perhitungan 1 tahun (1x $365 \times 20$ menit $)=7.300$ menit $=5$ hari $/$ setahun, 2,5 hari dibulatkan menjadi 3 hari/6 bulan. Pengukuran perubahan kekerasan dilakukan di Laboratorium Dental Material Fakultas Kedokteran Gigi Universitas Indonesia.

Pembuatan spesimen dilakukan dengan cara menyediakan spesimen dari potongan base plate wax. Gips jenis II dengan perbandingan air : bubuk sesuai aturan pabrik $=15 \mathrm{ml}: 20$ gr diaduk selama 30 detik. Permukaan dinding dalam kuvet diolesi tipis dengan vaselin kemudian kuvet diisi dengan adonan gips tipe II hingga penuh, lalu diaduk hingga rata. Model malam ditanamkan ke dalam kuvet, masing-masing kuvet diisi 2 buah spesimen. Permukaan malam rata dengan adonan gips. Kuvet atas dicobakan sebelum adonan gips mengeras. Setelah adonan gips pada kuvet bawah mengeras, kuvet atas dipasang, kemudian diisi dengan adonan gips tipe II dan digetarkan hingga rata. Dilakukan pengepresan hingga rapat (metal to metal). Didiamkan sampai mengeras (setting), yaitu kurang lebih selama 15 menit. Selanjutnya pengeluaran model malam dengan cara kuvet yang telah diikat dengan tali dimasukkan selama 5 menit ke dalam air yang telah dididihkan $100^{\circ} \mathrm{C}$. Kuvet diangkat, kemudian dibuka dan cairan malam dikeluarkan. Sisa-sisa malam dibersihkan dari kuvet. Pengolahan akrilik, bubuk polimer dan monomer dengan perbandingan $4,8 \mathrm{~g}: 2 \mathrm{ml}$ (sesuai dengan aturan pabrik) diaduk pada pot porselen sampai mencapai tahap dough stage. Adonan dimasukan ke dalam kuvet dan dilakukan pengepresan sehingga kelebihan adonan mengalir keluar. Kuvet dibuka dan kelebihan adonan dipotong dengan pisau. Bila tidak ada lagi kelebihan akrilik dan porus, kertas selofan dilepas dan dilakukan pengepresan akhir. Pemasakan akrilik dilakukan dengan cara kuvet dimasukkan ke dalam panci berisi air dengan temperatur kurang lebih $100^{\circ} \mathrm{C}$. Setelah air mendidih kembali kuvet dibiarkan selama 20 menit, kuvet diangkat dan dibiarkan selama 10 menit. Setelah dingin, kuvet dibuka dan spesimen diambil kemudian dihaluskan dengan amplas No.800-1200 sampai permukaannya rata dan tetap dijaga ukurannya. ${ }^{14}$

Pembuatan bahan perendaman (stok) kopi Ulee Kareng sebanyak $5 \mathrm{~g}$ yang dilarutkan dalam $120 \mathrm{ml}$ akuades. Setiap spesimen direndam dalam $5 \mathrm{ml}$ larutan kopi Ulee Kareng dan $5 \mathrm{ml}$ akuades untuk kelompok kontrol. Pengujian kekerasan permukaan dilakukan 2 kali, yaitu sebelum perendaman dan sesudah perendaman. Kekerasan masing-masing spesimen resin akrilik diukur dengan menggunakan alat uji kekerasan Knoop Microhardness (Shimadzu). Spesimen diletakkan pada alat ukur dan pengujian kekerasan dilakukan dengan tekanan indentasi sebesar $25 \mathrm{~g}$ selama 5 detik. Jarak spesimen diletakkan kurang lebih 300 $\mu \mathrm{m}$ di antara indentasi. Pengukuran dilakukan minimal sebanyak 3 indentasi pada setiap spesimen, lalu dihitung rerata kekerasannya. 
Hasil penelitian kemudian dianalisis dengan menggunakan uji non-parametrik Mann Whitney dan Wilcoxon yang terlebih dahulu dilakukan uji normalitas Kolmogorov-Smirnov.

\section{HASIL PENELITIAN}

Dari penelitian yang telah dilakukan, diperoleh hasil rerata dan standar deviasi dari pengukuran kekerasan resin akrilik sebelum dan sesudah perendaman dalam kelompok kontrol (yang direndam dalam akuades) dan kelompok perlakuan (yang direndam dalam minuman kopi Ulee Kareng) selama 3 hari seperti dilihat pada tabel 1.

Pengolahan data pengukuran kekerasan dianalisis dengan menggunakan SPSS 14. Hasil uji Kolmogorov-Smirnov diperoleh data terdistribusi tidak normal, maka dilanjutkan dengan uji non- parametrik Wilcoxon dan Mann Whitney.

Dari analisis Wilcoxon diperoleh penurunan nilai kekerasan yang bermakna antara sebelum dan sesudah perendaman baik dalam kelompok kontrol maupun kelompok perlakuan selama 3 hari $(\mathrm{P}<0,05)$. Pada analisis Mann Whitney menunjukkan adanya perbedaan kekerasan yang bermakna antara larutan kontrol dengan larutan perlakuan yang direndam selama 3 hari $(\mathrm{P}<0,05)$, yaitu pada perendaman dalam kelompok perlakuan didapat nilai KHN yang lebih rendah $(5,83)$.

\section{PEMBAHASAN}

Pada penelitian ini digunakan resin akrilik jenis heat cured merek QC-20 yang mempunyai nilai kekerasan $\pm 13 \mathrm{KHN}$. Menurut Craig, standar umum untuk nilai kekerasan resin akrilik adalah $21 \mathrm{KHN}^{15}{ }^{15}$ Namun menurut beberapa penelitian lain, dinyatakan bahwa basis resin akrilik memiliki nilai kekerasan yang tidak sama untuk setiap merek resin akrilik.

Pada penelitian Azevedo yang menggunakan basis gigitiruan resin akrilik dengan tiga merek yang tidak sama, didapatkan nilai kekerasan Lucitone
$550=25$ VHN, Kooliner $=10$ VHN dan Duraliner $=7 \mathrm{VHN}^{16}$

Penelitian yang telah dilakukan menunjukkan adanya penurunan kekerasan yang signifikan antara sebelum dengan sesudah perendaman selama 3 hari (baik pada kelompok kontrol maupun kelompok perlakuan). Terjadinya penurunan nilai kekerasan permukaan secara signifikan disebabkan oleh absorpsi air. ${ }^{3,16}$ Air memegang peranan penting dalam degradasi hidrolitik dan erosi bahan resin dengan cara meregangkan filler matriks. Telah diobservasi bahwa air dapat menurunkan kekerasan semua bahan setelah 2 hari perendaman pertama, karena air lebih bertindak sebagai plasticizer. ${ }^{16}$

Bahan berbahan dasar polimer dapat menyerap air ke dalam matriks melalui suatu proses difusi terkontrol. ${ }^{16}$ Molekul pelarut yang masuk akan memaksa ikatan polimer berjauhan sehingga menyebabkan ekspansi matriks. Akibatnya, kekuatan dari ikatan menurun sehingga polimer menjadi lebih lunak, pelunakan matriks segera terjadi setelah adanya penyerapan air sehingga kekerasan menurun. ${ }^{17}$ Menurut Nihei, resin akrilik yang direndam dalam air dapat menyerap molekul air. Resin mampu menyerap air sebab matriks resin bersifat hidrofilik, gugus fungsional dari matriks resin yaitu gugus hidroksi, eter dan ester memiliki afinitas tinggi terhadap $\mathrm{H}_{2} \mathrm{O} .{ }^{18}$ Berdasarkan teori degradasi matriks, resin yang direndam dalam air akan menyerap molekul air, dan air akan berpenetrasi ke dalam ruang intermolekuler rantai polimer sehingga interaksi polar menurun. Hal ini menyebabkan jarak antar rantai polimer meningkat, terjadi ekspansi matriks, kemudian matriks melunak sehingga terjadi penurunan kekerasan permukaan. ${ }^{17}$

Dari grafik pada Gambar 1 yang merupakan hasil konversi dari tabel 1, dapat diketahui bahwa minuman kopi Aceh Ulee Kareng dapat menurunkan kekerasan lebih rendah daripada akuades. Hal ini disebabkan karena minuman kopi Aceh Ulee Kareng selain mengandung air juga mengandung beberapa zat kimia yang juga dapat

Tabel 1. Nilai kekerasan KHN

\begin{tabular}{|c|c|c|c|c|c|c|c|c|c|}
\hline \multirow{2}{*}{ Larutan } & \multirow{2}{*}{$\begin{array}{l}\text { Lama perendaman } \\
\text { (hari) }\end{array}$} & \multicolumn{6}{|c|}{ Nilai kekerasan spesimen (KHN) } & \multirow{2}{*}{$\begin{array}{l}\text { Mean } \\
\text { KHN }\end{array}$} & \multirow{2}{*}{$\begin{array}{l}\text { Standar } \\
\text { deviasi }\end{array}$} \\
\hline & & 1 & 2 & 3 & 4 & 5 & 6 & & \\
\hline \multicolumn{10}{|l|}{ Akuades } \\
\hline Sebelum & 3 & 13,5 & 13,3 & 12,6 & 13,0 & 13,0 & 12,7 & 13,0 & $\mathbf{0 , 3 1}$ \\
\hline Sesudah & 3 & 13,3 & 10,3 & 10,8 & 9,8 & 9,3 & 10,3 & 10,6 & 1,32 \\
\hline \multicolumn{10}{|l|}{ Kopi UK } \\
\hline Sebelum & 3 & 12,9 & 13,9 & 12,8 & 13,8 & 13,1 & 13,3 & 13,3 & 0,42 \\
\hline Sesudah & 3 & 5,9 & 6,5 & 5,5 & 5,7 & 5,7 & 5,7 & 5,8 & $\mathbf{0 , 3 3}$ \\
\hline
\end{tabular}




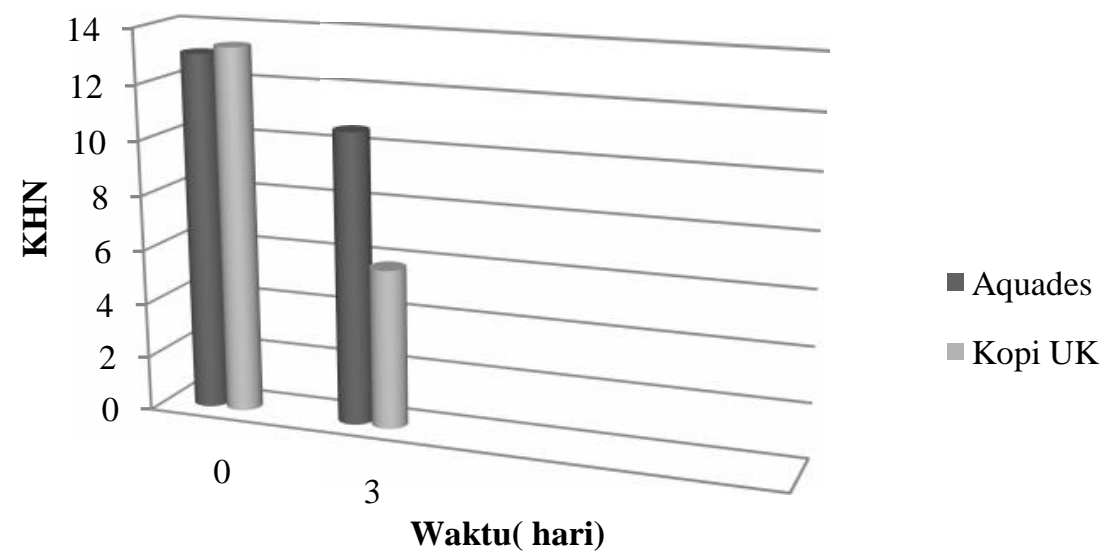

Gambar 1. Grafik perbandingan nilai kekerasan (KHN)

dikelompokkan menjadi asam (dengan $\mathrm{pH}$ sebelum dicampur air $=3$, sesudah dicampur air $=$ 5,74). Asam bersifat korosi terhadap semua bahan. Menurut teori "corrosive wear", terjadi kombinasi degradasi, yaitu degradasi kimia dan degradasi matriks berupa kelarutan matriks resin. ${ }^{19}$ Beberapa faktor yang dapat mempengaruhi tingkat degradasi polimer adalah ikatan kimia di dalam struktur polimer, $\mathrm{pH}$ medium perendaman, komposisi kopolimer dan kemampuan uptake air. $^{19}$ Air yang merupakan pelarut polar mengandung molekul pembawa yang baik dan dapat melarutkan serta membawa molekul asam seperti asam karboksilat dan trigonelin yang dikandung dalam minuman kopi Aceh Ulee Kareng. ${ }^{17}$ Hal tersebut menyebabkan dapat terjadi dua mekanisme penurunan kekerasan pada perendaman kopi Aceh Ulee Kareng, yaitu selain proses difusi air yang terkontrol, air juga membawa ion-ion hidrogen atau hidronium $\left(\mathrm{H}_{3} \mathrm{O}^{+}\right)$dari asam sehingga lebih banyak molekul hidrogen yang terserap dan melemahkan ikatan molekul resin akrilik dengan lebih mudah. Akibatnya penurunan nilai kekerasan terjadi lebih rendah lagi. ${ }^{20}$

\section{SIMPULAN}

Perendaman resin akrilik dalam akuades dan kopi Aceh Ulee Kareng selama 3 hari dapat menurunkan nilai kekerasan permukaan secara signifikan. Pada perendaman dalam minuman kopi Aceh Ulee Kareng didapatkan nilai kekerasan yang lebih rendah.

\section{SARAN}

Perlu dilakukan penelitian lebih lanjut menggunakan resin akrilik dengan merek lain yang mempunyai nilai kekerasan yang lebih tinggi, sehingga konsumen kopi dapat tetap menggunakan gigitiruannya dalam waktu yang lebih lama.

\section{DAFTAR PUSTAKA}

1. Haryanto AG. Buku ajar ilmu geligi tiruan sebagian lepasan. Jakarta: Hipokrates; 1991. h. 40-1.

2. Utari K. Kekerasan permukaan basis gigi tiruan polyester EBP 2421 dan resin akrilik setelah perendaman dalam larutan minuman. Dent J 2003; 36-4.

3. Philips RW. Science of dental material. $9^{\text {th }}$ Ed. Philadelphia: WB Saunder; 1991.

4. Kusdarjanti E. Kekuatan transversa resin akrilik jenis heat-cured yang direndam dalam minuman tuak. Dent J 2003; 36-4.

5. Anusavice KJ. Philip's science of dental material, $10^{\text {th }}$ Ed, Philadelphia: W.B. Saunders Company; 1996. p. 211-33.

6. Maughan RJ, Griffin J. Caffeine ingestion and fluid balance: a review. J Human Nutrition Dietetics 2003; 411-20.

7. Sri Mulato. Pelarutan biji kopi robusta dengan kolom tetap menggunakan pelarut air. Ringkasan penelitian; 2001. p.97-109.

8. Rustwiy D. Perbandingan khasiat sodium hipoklorit dengan sodium perborat dalam menghilangkan stain pada heat cured clear resin akrilik. J Indian Prosthodont Soc 2009; 6-12.

9. All about Coffee. Caffeine Level. Jeremiah's Pick Coffee Co; 2007

10. Lovett R. Coffee the demon drink. New Scientist (2518) Diunduh pada 7 November, 2008.

11. Arts IC, Hollman PC. Polyphenols and disease risk in epidemiologic studies. Am J Clin Nutr 2005; 81(1 Suppl): 317S-25S

12. Pudjirochani E. Kekuatan impak resin akrilik heatcured dan microwave cured setelah perendaman dalam teh hitam. Maj Ked Gigi 2000: 33. 
13. Fenomena Kopi Aceh. Diunduh 31 Januari 2007. Available from: http://www.uleekareng.com

14. Tim Penyusun Buku Panduan Praktik Ilmu Kedokteran Gigi Dasar. Praktikum/Demontrasi/ Reinforcement/Skill's Laboratory. Banda Aceh; 2007.

15. Craig RG, Powers JM, Wanata JC. Dental material: properties and manipulation. $7^{\text {th }}$ Ed. St. Louis: Mosby Inc; 2000. p. 261-2.

16. Azevedo A. Hardness of denture base and hardchair-side reline acrylic resins. J Appl Oral Sci 2005; 291-5.
17. Noort RV. Introduction to Dental Materials. $3^{\text {rd }}$ Ed. London: Mosby Elsevier; 2007. p. 62-4.

18. Nihei T. Enhanced hydrolytic stability of dental composites by use of fluoroalkyltrimethoxysilanes. J Dent Res 2002; 482-6.

19. Eliades G. Dental materials in vivo aging and related phenomena. Chicago: Quintessence Publishing Co, Inc; 2003.

20. Boonlert K. Vickers's microhardness and energy dispersive $\mathrm{X}$-ray analysis of fluorapatite-leucite and fluoapatite ceramics cyclically immersed in acidic agents. J Oral Sci 2009; 443-50. 